\title{
Simulations of atmospheric methane for Cape Grim, Tasmania, to constrain southeastern Australian methane emissions
}

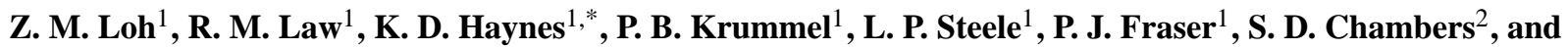 \\ A. G. Williams ${ }^{2}$ \\ ${ }^{1}$ Centre for Australian Weather and Climate Research, CSIRO Oceans and Atmosphere Flagship, \\ Private Bag 1, Aspendale, Vic 3195, Australia \\ ${ }^{2}$ Australian Nuclear Science and Technology Organisation, Locked Bag 2001, Kirrawee DC, NSW 2232, Australia \\ *now at: Department of Atmospheric Science, Colorado State University, Fort Collins, CO, USA
}

Correspondence to: R. M. Law (rachel.law@csiro.au)

Received: 1 August 2014 - Published in Atmos. Chem. Phys. Discuss.: 19 August 2014

Revised: 26 November 2014 - Accepted: 17 December 2014 - Published: 13 January 2015

\begin{abstract}
This study uses two climate models and six scenarios of prescribed methane emissions to compare modelled and observed atmospheric methane between 1994 and 2007, for Cape Grim, Australia $\left(40.7^{\circ} \mathrm{S}, 144.7^{\circ} \mathrm{E}\right)$. The model simulations follow the TransCom- $\mathrm{CH}_{4}$ protocol and use the Australian Community Climate and Earth System Simulator (ACCESS) and the CSIRO Conformal-Cubic Atmospheric Model (CCAM). Radon is also simulated and used to reduce the impact of transport differences between the models and observations. Comparisons are made for air samples that have traversed the Australian continent. All six emission scenarios give modelled concentrations that are broadly consistent with those observed. There are three notable mismatches, however. Firstly, scenarios that incorporate interannually varying biomass burning emissions produce anomalously high methane concentrations at Cape Grim at times of large fire events in southeastern Australia, most likely due to the fire methane emissions being unrealistically input into the lowest model level. Secondly, scenarios with wetland methane emissions in the austral winter overestimate methane concentrations at Cape Grim during wintertime while scenarios without winter wetland emissions perform better. Finally, all scenarios fail to represent a methane source in austral spring implied by the observations. It is possible that the timing of wetland emissions in the scenarios is incorrect with recent satellite measurements suggesting an austral spring (September-October-November), rather than winter, maximum for wetland emissions.
\end{abstract}

\section{Introduction}

Methane $\left(\mathrm{CH}_{4}\right)$ is an important greenhouse gas whose atmospheric concentration has more than doubled since the 18th century (MacFarling Meure et al., 2006), with considerable variations in its growth rate over recent decades (Rigby et al., 2008; Dlugokencky et al., 2009; Sussmann et al., 2012). Methane has both anthropogenic and natural emissions, while the main sink for methane is through reaction with hydroxyl radical $(\mathrm{OH})$ in the troposphere and by photolysis in the stratosphere. On a global scale, considerable uncertainty remains about the causes of recent changes in the methane growth rate (Kirschke et al., 2013), and on a regional level, significant discrepancies have been found between "bottom up" inventory estimates of emissions and "top down" atmospheric inverse modelling studies. For example, in Miller et al. (2013), the authors find that the inventories underestimate emissions by up to 2.7 times in the south-central USA.

Atmospheric concentrations of methane are measured approximately weekly at more than 150 flask-sampling sites worldwide and continuously at a smaller number of in situ instrumented sites. Some of the longer in situ records are those of the Advanced Global Atmospheric Gases Experiment (AGAGE) network (Cunnold et al., 2002), including the record from Cape Grim, Australia. A number of global modelling studies have used such methane atmospheric records to constrain the methane budget - for example, Fung et al. (1991), Houweling et al. (1999) and Bousquet et al. (2011). Rigby et al. (2008) used the AGAGE in situ 
methane and CSIRO flask methane data, together with the AGAGE methyl chloroform records to deduce the Northern Hemisphere and Southern Hemisphere changes in methane emissions required to account for the measured increase in methane mole fraction growth rate from 2007.

Recently a model intercomparison, "TransCom- $\mathrm{CH}_{4}$ ", has been run for methane (Patra et al., 2011), with a focus on understanding how transport model differences contributed to variations in the methane simulations. All model simulations used the same prescribed methane emissions and modelled methane loss using prescribed, climatological $\mathrm{OH}$ fields. We have used the simulations defined for this intercomparison to compare simulated and measured methane at Cape Grim, with the goal of evaluating the accuracy of the prescribed methane emissions for southeastern Australia. The model intercomparison also simulated radon, sulfur hexafluoride $\left(\mathrm{SF}_{6}\right)$ and methyl chloroform $\left(\mathrm{CH}_{3} \mathrm{CCl}_{3}\right)$ as additional tests for different components of the transport model. Radon $\left({ }^{222} \mathrm{Rn}\right)$ is emitted reasonably uniformly in both space and time from land surfaces at much higher rates than from oceans and decays radioactively with a half-life of 3.8 days. Due to its short lifetime, radon is often used as a tracer of recent contact with land and to explore vertical mixing through the lower atmosphere (Zahorowski et al., 2004; Williams et al., 2011, 2013; Chambers et al., 2011). Since radon fluxes are usually assumed to be better characterized than fluxes of other trace gases, radon has been used, via tracer ratio methods, to estimate regional carbon dioxide, methane and nitrous oxide or other greenhouse gas fluxes (Schmidt et al., 1996; Wilson et al., 1997; Biraud et al., 2000; Zahorowski et al., 2004; Wada et al., 2013).

An Australian methane budget was described by Wang and Bentley (2002), who used 1997 Cape Grim atmospheric methane measurements in an inversion to constrain the methane fluxes from southern Australia. Their study suggested that the methane inventory overestimated southeastern Australian fluxes. A more recent modelling study by Fraser et al. (2011) ran forward model simulations for 2005-2008 and separated methane into different regional and process-based components, focusing on better parameterizing methane fluxes from seasonal wetlands in tropical Australia. At Cape Grim, they found their simulated methane was dominated by animal, landfill and ocean fluxes. They also noted that their model reproduced background, baseline methane concentrations at Cape Grim well, but the model was less successful in reproducing concentrations influenced by local emissions. The concentration excursions driven by local emissions are typically large in magnitude and are referred to as "non-baseline" events. These events contain information regarding regional fluxes and are the focus of this study.

To investigate non-baseline events, this study uses both observations at Cape Grim and forward model simulations with prescribed emissions. Sections 2 and 3 describe the observations at Cape Grim and the model simulations, respectively.

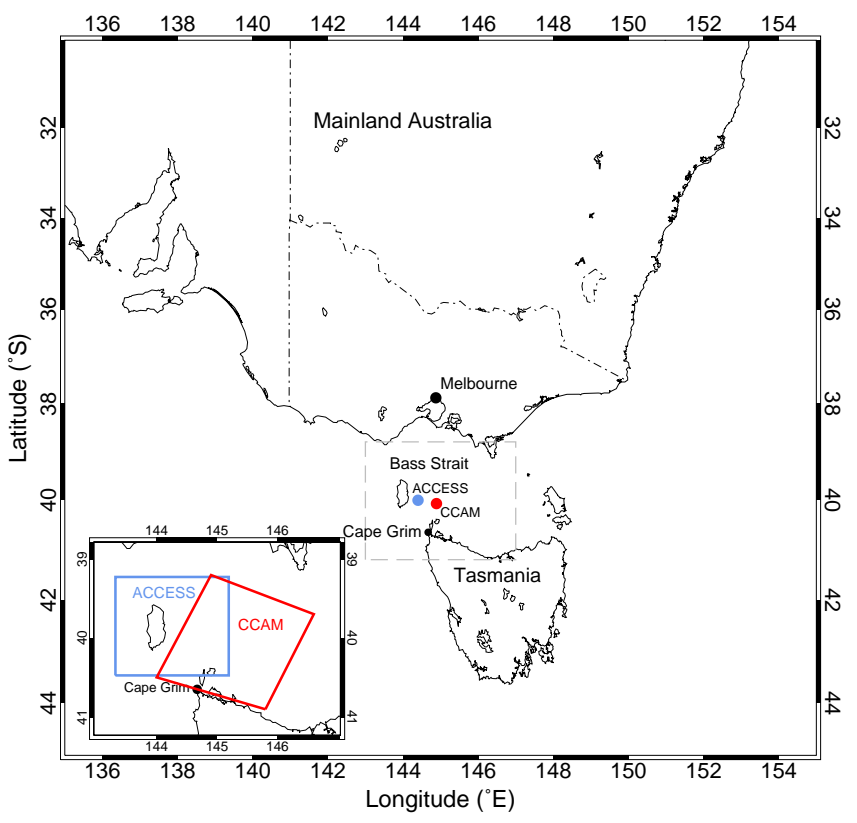

Figure 1. Map of southeastern Australia, showing the location of the Cape Grim Baseline Air Pollution Station, along with the ACCESS (blue) and CCAM (red) grid points selected to best represent Cape Grim. The choice of these grid points is discussed in Sect. 4.2. The inset shows the extent of each of the grid cells.

Section 4 focuses on seasonal-scale results, exploring an apparent anomaly between modelled and observed methane in austral spring. The implications for regional methane fluxes are discussed in Sect. 5.

\section{Observations}

Cape Grim is located at the top of a $90 \mathrm{~m}$ cliff on the northwest coast of Tasmania $\left(40.7^{\circ} \mathrm{S}, 144.7^{\circ} \mathrm{E}\right)$, which is separated from mainland Australia by Bass Strait (Fig. 1). The Cape Grim station has been operating since the 1970s and now has the most comprehensive monitoring programme in the Southern Hemisphere for greenhouse gases (Langenfelds et al., 2014), ozone-depleting gases (Krummel et al., 2014) and radon (Zahorowski et al., 2014).

Figure 2 shows methane and radon observations made at Cape Grim during 2006. Observations made at Cape Grim are characterized by baseline periods when the wind is from the southwest (typically $30 \%$ of the time), and air parcels have had long trajectories over the Southern Ocean. During these periods, concentrations are reasonably steady displaying underlying seasonal variations and long-term trends. Baseline periods are punctuated by non-baseline events characterized by higher concentrations that vary rapidly in time, indicative of air parcel trajectories that have travelled over mainland Australia or Tasmania, and consequently have been influenced by regional and local emissions. The seasonal cy- 

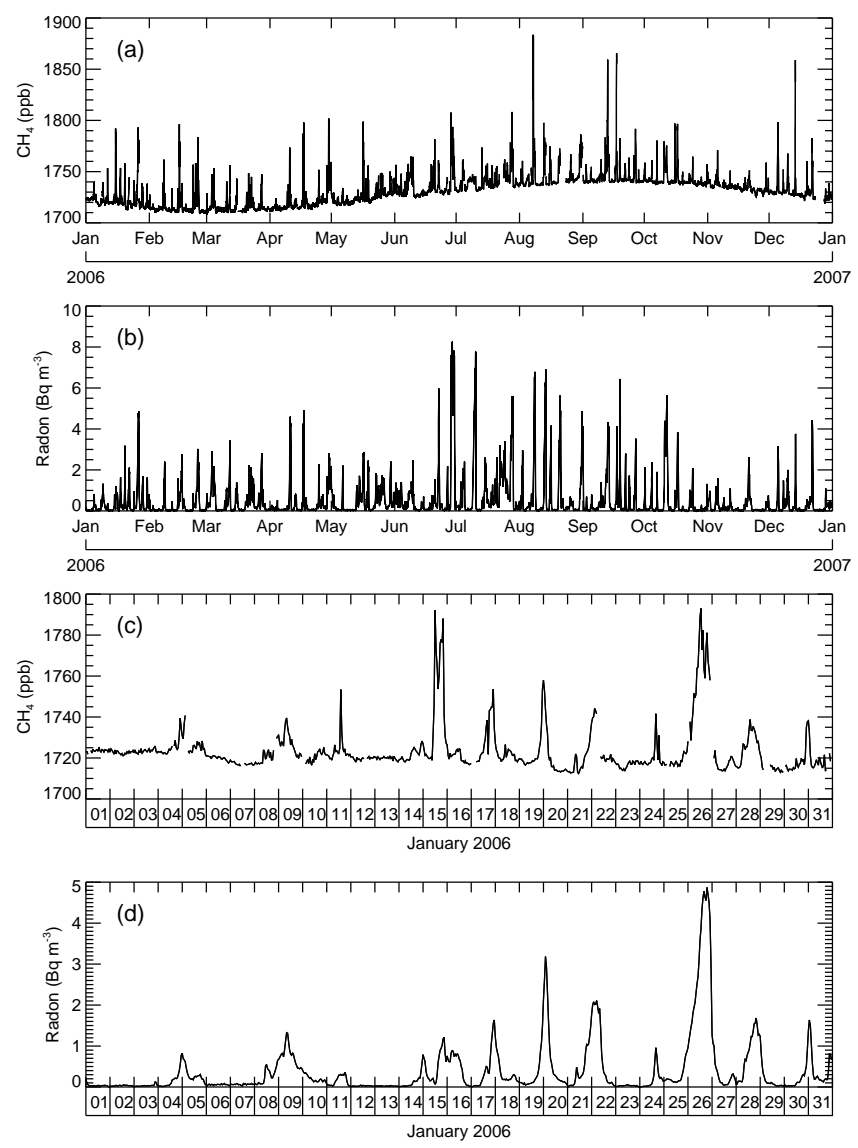

Figure 2. Cape Grim observations (a) 2006 methane data (b) 2006 radon data (c) January 2006 methane data and (d) January 2006 radon data.

cles in both methane and radon are apparent in Fig. 2a and b which show a full year of data. In Fig. $2 \mathrm{c}$ and d, showing just one month of data, the difference between baseline periods and non-baseline events can be more clearly seen and one gets a sense of the degree to which methane and radon are correlated.

Flask measurements of $\mathrm{CH}_{4}$ began at Cape Grim in 1984, while the record from the current AGAGE GC-MD (multigas chromatograph, multi-detector) in situ instrument system, which incorporates a Carle GC fitted with a flame ionization detector (see Prinn et al., 2000) began late in 1993. Ambient methane measurements are made on discrete air samples every $40 \mathrm{~min}$, taken alternately from a 75 and $10 \mathrm{~m}$ inlet for the majority of the study period. The data from both inlets are used in this study. Ambient samples are bracketed by analysis of a calibration standard, and the resulting $\mathrm{CH}_{4}$ record is reported on the Tohoku University scale (Aoki et al., 1992; Prinn et al., 2000).

During the period of observations used for this study, Cape Grim radon measurements were made using a number of detectors. From 1994 to 1997, a 9000 L two-filter radon detector featuring a particle generator was used, operating at a nominal flow rate of $200 \mathrm{Lmin}^{-1}$ and with a response time of approximately $90 \mathrm{~min}$ (Whittlestone and Zahorowski, 1995). From 1997, a newly designed $5000 \mathrm{~L}$ dual flow loop, two-filter radon detector was commissioned, operating at a nominal flow rate of $285 \mathrm{~L} \mathrm{~min}^{-1}$ and with a response time of $45 \mathrm{~min}$ (Whittlestone and Zahorowski, 1998). Later developments saw this new detector enhanced from a single-head design to two and eventually four heads in 2004 , with corresponding improvements to sensitivity and lower limit of detection. Air was sampled from a $75 \mathrm{~m}$ inlet, the same height as the upper $\mathrm{CH}_{4}$ observations. Raw radon counts were collected half-hourly and aggregated to hourly values during post-processing. Detector sensitivity ranged from 0.6 to 1.2 counts per second per $\mathrm{Bqm}^{-3}$ during the period of measurements. Calibrations were performed monthly using a Pylon flow-through radon source (20.9 $\pm 0.8 \mathrm{kBq}$ Radium-226), traceable to US National Institute of Standards and Technology (NIST) standards, and instrumental background checks were performed approximately every 3 months. The lower limit of detection for the Cape Grim radon detectors, defined as the radon concentration below which the statistical counting error exceeds $30 \%$, ranged from 6 to $10 \mathrm{mBq} \mathrm{m}^{-3}$.

For this study, $\mathrm{CH}_{4}$ observations from 1994-2007 have been processed using the following steps:

1. We have linearly interpolated between the discrete measurements of atmospheric $\mathrm{CH}_{4}$ every $40 \mathrm{~min}$, to generate hourly $\mathrm{CH}_{4}$ data, to facilitate comparisons with the hourly radon data, and the hourly values from the model simulations.

2. The $\mathrm{CH}_{4}$ observations were then selected for baseline conditions by excluding all hours when the coincident radon measurement was greater than $100 \mathrm{mBq} \mathrm{m}^{-3}$.

3. A smooth curve was then found through these baselineselected $\mathrm{CH}_{4}$ observations using the methodology described in Thoning et al. (1989). Specifically, the baseline data are fitted with a function consisting of a second-order polynomial and four harmonics. This function fit is then subtracted from the baseline data and the resulting residuals are then filtered with a band-pass filter with a short-term cut-off of 80 days. The original function fit is then added back to the filtered residuals to give a smooth curve fit through the data. This procedure is performed iteratively, and in each iteration, the individual hours that lie outside twice the standard deviation around the fit are excluded until the fit converges.

4. Lastly, the smooth curve fitted to the baseline data is subtracted from all $\mathrm{CH}_{4}$ observations to give a time series of residuals. In most cases it is only the residuals from hours that have been flagged as non-baseline that are used for comparison with the model simulations. 


\section{Model simulations}

This study uses simulation experiments that were run for the TransCom- $\mathrm{CH}_{4}$ model intercomparison to investigate various methane flux estimates. The TransCom- $\mathrm{CH}_{4}$ model intercomparison involved running nine tracers in a global atmospheric model for the years 1988-2007. The first six tracers used different methane emission scenarios. The remaining three tracers were radon, sulfur hexafluoride and methyl chloroform. In each methane case, chemical loss of methane was simulated using prescribed $\mathrm{OH}$ fields (with seasonal variations but no interannual variations) and prescribed loss rates to represent photolysis in the stratosphere. The emissions are described in detail and a global analysis of the results is presented in Patra et al. (2011). Other details can also be found online in the TransCom- $\mathrm{CH}_{4}$ protocol (Patra et al., 2010).

\subsection{Methane emission scenarios}

The six methane scenarios were created by combining various estimates of anthropogenic, rice, biomass burning and wetland components in different ways (Table 1). Details are given in Patra et al. (2011) and we use the same emission scenario labels as used in that paper and across the TransCom- $\mathrm{CH}_{4}$ project. The control (CTL) scenario uses anthropogenic fluxes as specified in the Emissions Database for Global Atmospheric Research (EDGAR) inventory, version 3.2 (Olivier and Berdowski, 2001) and includes fossil fuel, industrial, animal, fire, waste and biofuel emissions. Added to these fluxes are seasonally varying (no interannual variability) natural fluxes comprising biomass burning from Fung et al. (1991), wetland emissions (Matthews and Fung, 1987; Fung et al., 1991) and rice (Yan et al., 2009).

Four alternative emissions scenarios change one or more of the CTL component fluxes. CTL_E4 uses EDGAR 4.0 (van Aardenne et al., 2001) for the anthropogenic component; BB (biomass burning) uses biomass burning emissions from the Global Fire Emissions Database, version 2 (van der Werf et al., 2006) (including interannual variations when available); WLBB (wetland and biomass burning) additionally includes interannually varying wetland emissions (Ringeval et al., 2010); EXTRA uses the same biomass burning as BB and interannually varying model generated wetlands and rice emissions from the VISIT model (Ito and Inatomi, 2012). A final emissions scenario, INV, does not use fluxes from inventories or process models but those estimated by the atmospheric inversion of Bousquet et al. (2006). All six emissions scenarios use the same soil sink. Table 2 details which components of each scenario include interannual variability and in which years of the simulations.

Figure 3a shows the aggregated emissions for the region of southeastern Australia bounded by $135-155^{\circ} \mathrm{E}$ and $45-30^{\circ} \mathrm{S}$ which is the region shown in Fig. 1. The emissions show a seasonal cycle that is dominated by the wetland component
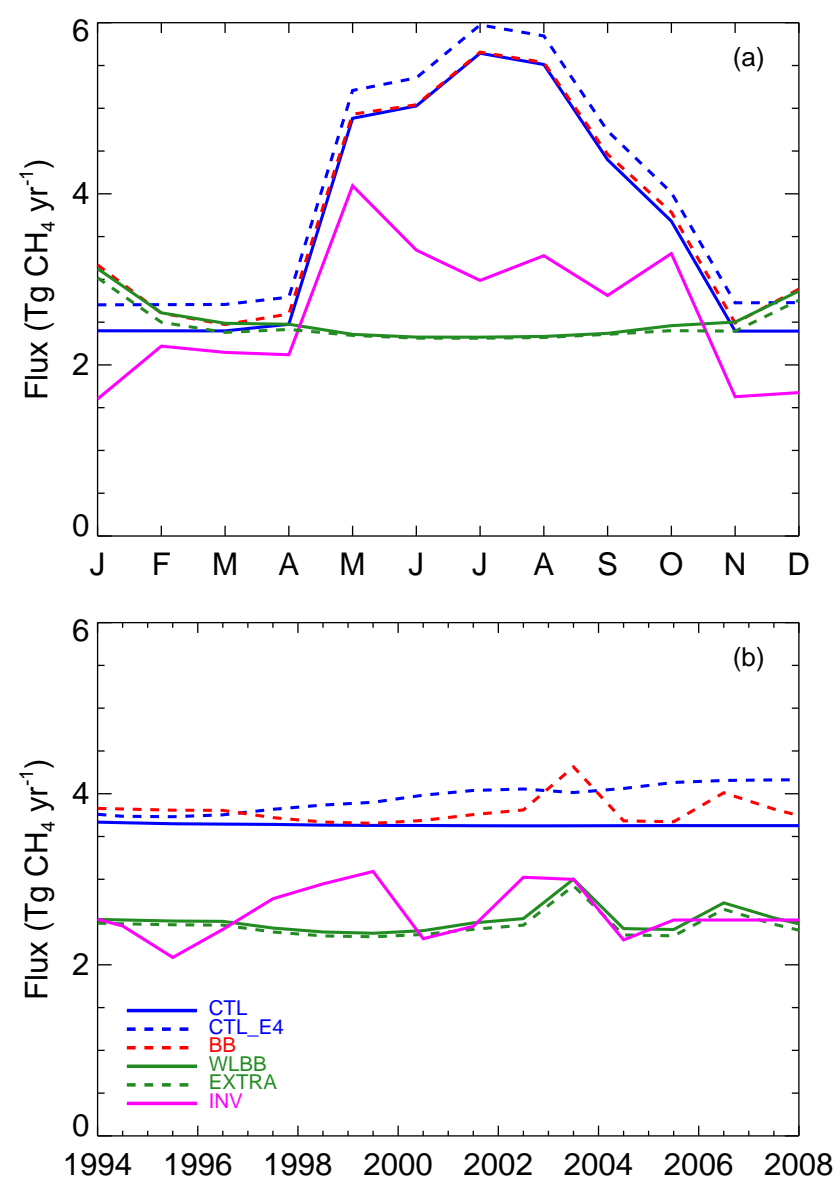

Figure 3. Seasonal cycle (a) and annual mean (b) methane fluxes for 1994-2007 integrated over the SE Australian region (135$\left.155^{\circ} \mathrm{E}, 30-45^{\circ} \mathrm{S}\right)$. Six flux scenarios are shown as listed in the key.

for CTL, CTL_E4 and BB with higher emissions from May to October. The seasonality is much smaller for the WLBB and EXTRA scenarios with maximum fluxes in December and January due to biomass burning. The INV emissions show similar seasonality to the CTL emissions, though with smaller amplitude. It is worth noting that the inversion used to generate these fluxes included only baseline $\mathrm{CH}_{4}$ data at Cape Grim, so there is no reason to expect the INV fluxes to fit the non-baseline record at Cape Grim better than the other flux scenarios.

Figure $3 b$ shows the interannual variability of the prescribed emissions, again aggregated over the region shown in Fig. 1. The CTL fluxes show almost no change in time, while the CTL_E4 fluxes increase over time. The three fluxes that include interannually varying biomass burning - BB, WLBB and EXTRA - show peaks in 2003 and 2006 associated with significant summer fires in southeastern Australia. This will be discussed in more detail in Sect. 4.1. The INV fluxes show the greatest interannual variability in this region.

The prescribed TransCom- $\mathrm{CH}_{4}$ methane emissions can be compared with those reported in Wang and Bentley (2002) 
Table 1. The broad components of the methane emission scenarios. The anthropogenic category includes fossil fuel, industrial, animal, fire, waste and biofuel emissions. See Patra et al. (2011) for further details of how the emission scenarios were constructed.

\begin{tabular}{|c|c|c|c|c|}
\hline Code & Anthropogenic & Rice & Biomass burning & Wetlands \\
\hline CTL & EDGAR3.2 & Yan et al. (2009) & Fung et al. (1991) & Matthews and Fung (1987); Fung et al. (1991) \\
\hline CTL_E4 & EDGAR4.0 & Yan et al. (2009) & Fung et al. (1991) & Matthews and Fung (1987); Fung et al. (1991) \\
\hline $\mathrm{BB}$ & EDGAR3.2 & Yan et al. (2009) & van der Werf et al. (2006) & Matthews and Fung (1987); Fung et al. (1991) \\
\hline WLBB & EDGAR3.2 & Yan et al. (2009) & van der Werf et al. (2006) & Ringeval et al. (2010) \\
\hline EXTRA & EDGAR3.2 & Ito and Inatomi (2012) & van der Werf et al. (2006) & Ito and Inatomi (2012) \\
\hline INV & \multicolumn{4}{|c|}{ LSCE Inversion Bousquet et al. (2006) } \\
\hline
\end{tabular}

Table 2. Methane emission scenarios, indicating which components have interannual variations over different periods. A mean seasonal cycle is used outside the listed periods.

\begin{tabular}{lcccc}
\hline Code & Anthropogenic & Rice & Biomass burning & Wetlands \\
\hline CTL & $1990: 1995: 2000$ & No & No & No \\
CTL_E4 & $1990-2005$ & No & No & No \\
BB & As CTL & No & $1996-2008$ & No \\
WLBB & As CTL & No & As BB & $1994-2000$ \\
EXTRA & As CTL & $1988-2008$ & As BB & $1988-2008$ \\
INV & \multicolumn{5}{c}{$1988-2005$} \\
\hline
\end{tabular}

Table 3. Annual flux emissions (in $\mathrm{Tg}^{-1}$ ) from southeastern Australia for different years and from different sources.

\begin{tabular}{lcc}
\hline Source & Year & Flux \\
\hline Wang and Bentley (2002) inventory & 1997 & 3.09 \\
Wang and Bentley (2002) inversion & 1997 & 1.93 \\
Fraser et al. (2011) & 2008 & 2.88 \\
This study & 1997 & $2.38-3.82$ \\
This study & 2008 & $2.34-4.16$ \\
\hline
\end{tabular}

and Fraser et al. (2011) (Table 3). To approximate our region of interest, from Wang and Bentley (2002) we sum their regions $\mathrm{A}, \mathrm{C}$ and $\mathrm{D}$, which extend slightly further west and north than our region. This gives total anthropogenic emissions (agriculture including cattle, the energy and transport sectors and waste management) of $3.39 \mathrm{Tg}^{-1}$, using the methodology of the Australian National Greenhouse Gas Inventory (NGGI) coupled with statistical data for 1997 to give a spatially explicit representation of methane emissions. By adding in an estimate of methane uptake by Australian soils, the net anthropogenic flux used in Wang and Bentley (2002) across southeastern Australia is $3.09 \mathrm{Tg}^{-1}$. Wang and Bentley (2002) also adjust their inventory-based estimate by fitting atmospheric $\mathrm{CH}_{4}$ at Cape Grim using an inversion technique. This gives a substantially lower flux estimate $\left(1.93 \mathrm{Tg}^{-1}\right)$.

From Fraser et al. (2011) we sum their anthropogenic emissions (agriculture including cattle (and rice, which is very small), the energy sector, waste management and a small amount of prescribed burning) from five regions - New South
Wales, Australian Capital Territory, Victoria, Tasmania and South Australia - to give total anthropogenic emissions of $2.88 \mathrm{Tgy}^{-1}$ for 2008. Fraser et al. (2011) take emissions from the EDGAR 3.2 inventory (Olivier et al., 2005), and scale them to the Australian NGGI. Both inventories have total annual $\mathrm{CH}_{4}$ emissions which are closer to the annual emissions of the lower set of methane scenarios used here, but the inventories do not include natural fluxes while the TransCom methane scenarios do. In southeastern Australia, the major natural flux is from wetlands, but the magnitude of this flux is uncertain. The CTL-based emission scenarios (CTL, CTL_E4 and BB) include a large $1.24 \mathrm{Tgy}^{-1}$ component from wetlands for southeastern Australia, taken from Matthews and Fung (1987) and Fung et al. (1991). The WLBB and EXTRA emission scenarios take their estimates of wetland emissions from Ringeval et al. (2010) and Ito and Inatomi (2012), which are close to zero for southeastern Australia. Wetland emissions will be discussed further in Sects. 4.2 and 5.

\subsection{Atmospheric models}

We have run the TransCom- $\mathrm{CH}_{4}$ simulations with two models: the CSIRO Conformal-Cubic Atmospheric Model (CCAM) (McGregor, 2005; McGregor and Dix, 2008) and the Australian Community Climate and Earth System Simulator (ACCESS) (Corbin and Law, 2011). Using two models allows us to better understand any sensitivity in the analysis to model transport error.

The first model, CCAM, has an approximately uniformly spaced conformal cubic grid and was run with a horizon- 
tal resolution of approximately $220 \mathrm{~km}$, and 18 levels in the vertical. The horizontal components of the wind were nudged (Thatcher and McGregor, 2009) to NCEP analyses (Kalnay et al., 1996; Collier, 2004). This helps to ensure that simulated atmospheric concentrations of trace gases can be more realistically compared to observations on synoptic timescales. The CCAM simulations analysed here are the same as those submitted to the TransCom- $\mathrm{CH}_{4}$ experiment (Patra et al., 2011).

The second model, ACCESS, is derived from the UK Met Office Unified Model but has the land surface scheme replaced by the Community Atmosphere Biosphere Land Exchange (CABLE) model. For this study, ACCESS was run at $1.875^{\circ}$ longitude by $1.25^{\circ}$ latitude, with 38 levels in the vertical. This is a higher horizontal resolution (to better represent the region around Cape Grim) than the ACCESS case submitted to the TransCom- $\mathrm{CH}_{4}$ experiment, which was run at $3.75^{\circ}$ longitude by $2.5^{\circ}$ latitude. In both cases, ACCESS was run without any nudging to analysed winds or temperature, so that the tracer transport is dependent on the ACCESS simulation of meteorological fields forced with observed monthly sea surface temperatures. Consequently, the output from this model is not expected to reproduce observed day-to-day variations in methane concentration and comparison with the observations is limited to seasonal or longer timescales. The ACCESS run used a 360-day calendar with 12 months of equal length.

It is important to consider where the model output is sampled to be most comparable with Cape Grim observations, as well as to minimize differences between the two model simulations. The model sampling locations are shown in Fig. 1. The inset in Fig. 1 shows the spatial extent of each of the grid cells chosen to represent Cape Grim, giving a sense of their relative size. For both models we have sampled slightly to the north of Cape Grim. For CCAM, this grid cell was chosen as it is the nearest ocean grid point to the location of Cape Grim. For ACCESS, the grid cell was chosen based on a radon simulation; the grid cell to the north of Cape Grim gave a better simulated seasonal cycle amplitude for radon than grid cells to the south or west. It is worth noting that in CCAM grid cells are either all land or all ocean, whereas in ACCESS fractional land area is allowed.

Model time series are output hourly. The simulated concentrations are processed in the same manner as for the observations. Firstly coincident radon concentrations are used to select for baseline $\mathrm{CH}_{4}$, a smooth curve is fitted to the baseline data, and the baseline fit is removed from the time series. The residual concentrations are used for comparison with the observations.

\section{Results}

Initial analysis of the simulated $\mathrm{CH}_{4}$ at Cape Grim highlighted two features. The first feature was two periods, De-
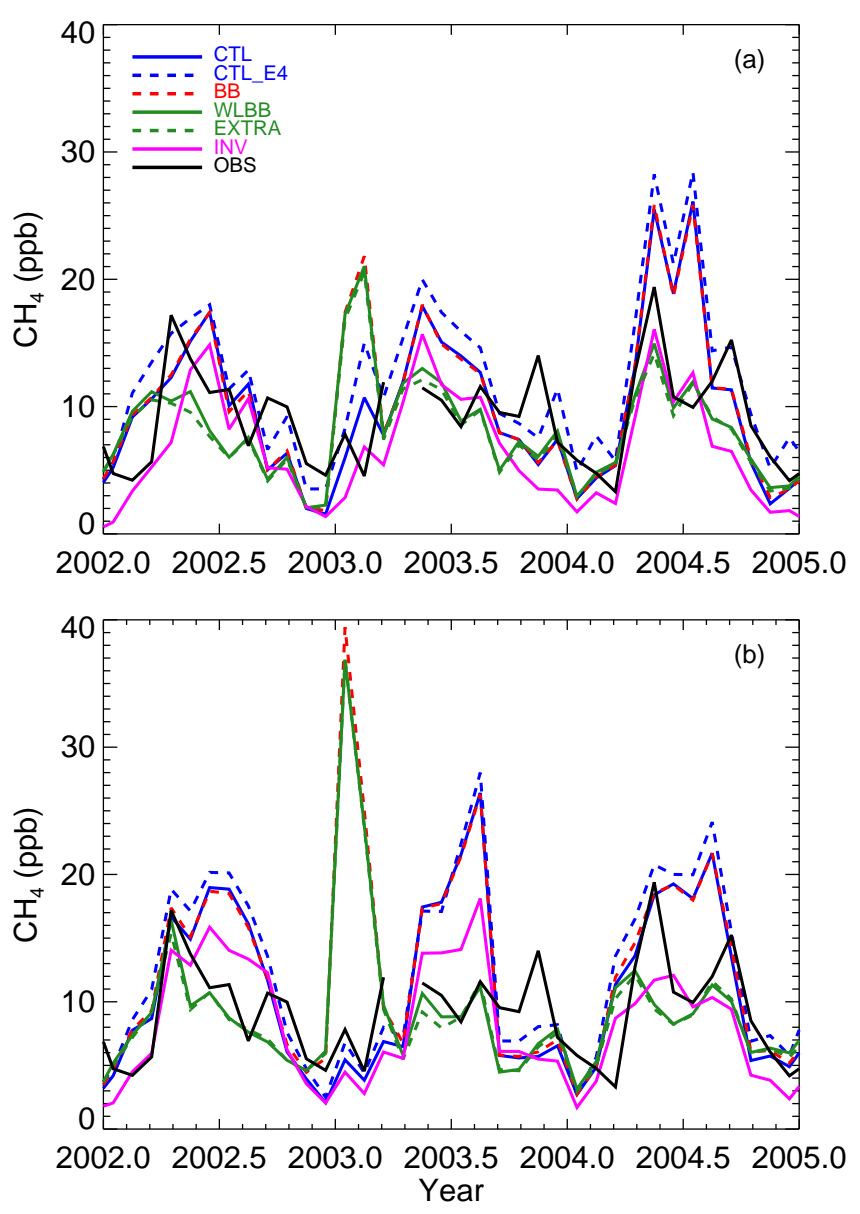

Figure 4. Monthly mean methane residuals for 2002-2004 at Cape Grim for the observations (black) and six emission scenarios (colours shown in key): (a) ACCESS (b) CCAM. Note that the observational mean residual for April 2003 is missing, due to lack of radon data with which to define the baseline threshold (rather than a lack of methane data).

cember 2002 to February 2003 and November 2006 to January 2007, with very high peak $\mathrm{CH}_{4}$ concentrations for the flux scenarios that included interannually varying biomass burning. The second feature was a large difference in $\mathrm{CH}_{4}$ concentrations in each winter between different flux scenarios.

As an example of these features, Fig. 4 shows the monthly mean methane residuals for three years (2002-2004) for the observations and all emission scenarios for both models. Both features mentioned above are most obvious in the CCAM results (Fig. 4b), where the model predicts exceptionally high methane concentrations in January and February 2003 for those tracers that include interannually varying biomass burning (BB, WLBB and EXTRA). Over the winter months, the three emission scenarios with default wetland emissions (CTL, CTL_E4 and BB) all produce higher methane concentrations than the observations or the remaining emission scenarios using modified wetland emissions 

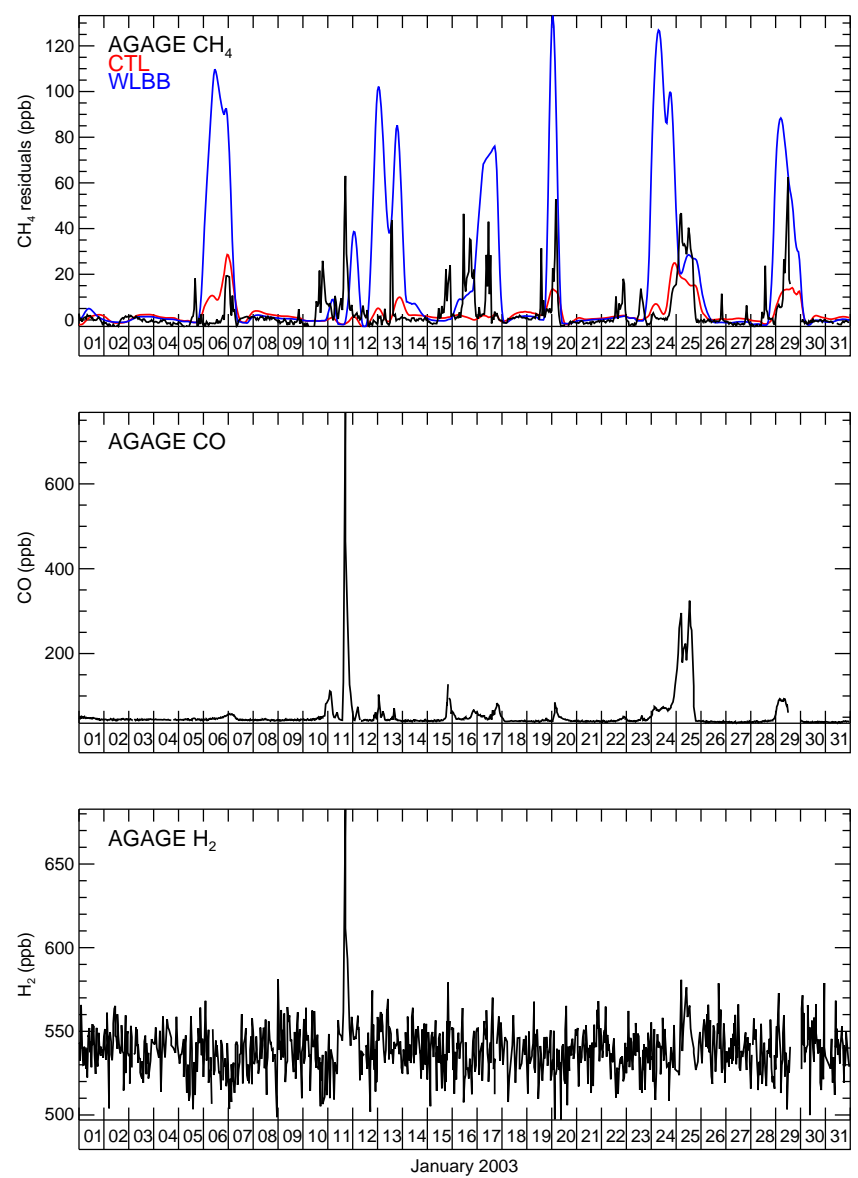

Figure 5. Cape Grim data for January 2003. Upper panel: observed (black) $\mathrm{CH}_{4}$ residuals; CCAM simulated residuals for tracers CTL (red) and WLBB (blue). Middle panel: observed CO. Lower panel: observed $\mathrm{H}_{2}$.

(WLBB and EXTRA) or based on the inversion of Bousquet et al. (2006) (INV).

\subsection{Biomass burning}

Figure 5 shows observed and CCAM simulated $\mathrm{CH}_{4}$ residuals for January 2003 as well as observed hydrogen $\left(\mathrm{H}_{2}\right)$ and carbon monoxide $(\mathrm{CO})$. High $\mathrm{H}_{2}$ and $\mathrm{CO}$ are signatures of air influenced by biomass burning. Two simulated $\mathrm{CH}_{4}$ tracers are shown, one which includes interannually varying biomass burning emissions (WLBB) and one that does not (CTL). The inclusion of "hot spots" of biomass burning emissions produces very large methane concentrations, much larger than those observed. Significant fires did occur during this period in the eastern Victorian alpine region starting on 8 January 2003 and burning around 1.3 million hectares over close to two months (http://www.depi.vic.gov.au/fireand-emergencies/managing-risk-and-learningabout-managing-fire/bushfire-history/maps-of-past- bushfires) and around Canberra between 18 and 21 January 2003. The observations indicate that the Victorian fire was likely seen briefly at Cape Grim on 11 January, when $\mathrm{CH}_{4}$, $\mathrm{H}_{2}$ and $\mathrm{CO}$ all had elevated concentrations. It is less clear what contribution biomass burning makes to other elevated methane events later in the month, when only small $\mathrm{CO}$ elevations are seen and $\mathrm{H}_{2}$ signals do not rise above the instrumental noise (except perhaps around 25 January).

There are a number of reasons why the models may overestimate the impact of this fire at Cape Grim. Firstly, the biomass burning emissions are specified at the middle of each month and interpolated to the middle of the previous and following months. This means that a January fire is spread temporally into December and February. Indeed, WLBB also shows very large $\mathrm{CH}_{4}$ concentrations in December 2002 and February 2003 (not shown). Secondly, the fire emissions were provided on a $1^{\circ} \times 1^{\circ}$ grid and have been regridded to the lower resolutions of the atmospheric models. In reality, the active fire at any given time would have covered a much smaller area. Finally, the fire itself would modify the local circulation, with emissions likely distributed not just near the surface but throughout the entire lower troposphere. This is not captured in our simulations where the emissions are input only to the lowest model level. For instance, Sofiev et al. (2013) find that, under Australian fire conditions, $90 \%$ of mass is emitted from the surface up to $3 \mathrm{~km}$ altitude.

To test the sensitivity to the height that emissions are input to the atmosphere, we have performed some short tests, running CCAM from December 2002 to February 2003, with only biomass burning emissions. Six tests were performed, releasing the emissions into model levels $1,3,5,7$ and 9 in turn (centred at approximately 40, 470, 1420, 2880, $4870 \mathrm{~m}$ respectively), or distributed through all levels 1-9. In general we find that the simulated timing of elevated $\mathrm{CH}_{4}$ events at Cape Grim is similar across the six tests but the amplitude of the events varies with emission insertion height. For example, the mean January $\mathrm{CH}_{4}$ concentration at Cape Grim is reduced from $16 \mathrm{ppb}$ for emissions inserted into level 1 to $12,7,2$ and $0.3 \mathrm{ppb}$ as emissions are input higher into the atmosphere. For the case where emissions are spread between levels 1 and 9, the mean January $\mathrm{CH}_{4}$ concentration is $5 \mathrm{ppb}$. While these simulations (modelling only the biomass burning component) are not directly comparable to the observations, they clearly illustrate one reason why the amplitude of events at Cape Grim could be overestimated. The frequency of events appears to be more strongly controlled by the temporal and spatial (horizontal) resolution of the emissions.

\subsection{Relationship between methane and radon: seasonal cycle}

Given the variation in simulated winter $\mathrm{CH}_{4}$ concentrations from the different flux scenarios, we would like to determine which gives a better comparison with the observations. To avoid biasing our analysis of the seasonality of methane 
by the very large concentrations caused by the interannually varying biomass burning fluxes, we remove the biomass burning contribution from BB, WLBB and EXTRA for the months December 2002 to February 2003 and also November 2006 to January 2007, when another large fire gives unrealistically high simulated concentrations of $\mathrm{CH}_{4}$ at Cape Grim. This was achieved by subtracting (BB - CTL) from each of the three affected tracers, during the months in question.

To minimize the impact of any errors in modelled atmospheric transport, we consider the ratio of methane residual concentrations to radon concentrations. The time series of methane residuals at Cape Grim is reasonably well correlated with radon, with both showing significantly elevated concentrations when air parcels have travelled over continental Australia. For the period 1994-2007, the correlation coefficient between observed methane residuals and observed radon is 0.65 . In the model simulations, correlations between residual methane and radon vary across methane scenarios between $0.81-0.87$ for ACCESS and $0.88-0.89$ for CCAM. The higher correlation coefficients for the modelled data set compared to the observed data set presumably reflect the reduced spatial variability of both $\mathrm{CH}_{4}$ and radon in the gridded models compared to the real world.

The strategy of using a residual methane to radon ratio to minimize transport errors relies on the assumption that both sources are similarly distributed. We note that this assumption is only loosely true. The methane emission scenarios we assess here have considerable spatial variability (though doubtless less than the real world), while the TransCom$\mathrm{CH}_{4}$-specified radon emissions are uniform over land. Land surface emissions of radon do vary (Griffiths et al., 2010), though much less than for methane. As a check on our sensitivity to radon spatial variability, we ran ACCESS for 3 years using a series of different radon flux fields taken from Griffiths et al. (2010). In general, neither the spatial variability nor the interannual variability appeared to have a significant impact on our sampled concentrations at Cape Grim. We found that the choice of grid cell was much more influential in the modelled radon results matching the observed radon results, hence our choice of ocean grid cells to the north of Cape Grim. One of the reasons for this is likely to be the coarseness of the grid cells: see Sect. 3.2 and refer to the inset in Fig. 1.

We examine the seasonal relationship between methane residuals and radon by fitting a linear relationship to all hourly non-baseline methane-radon pairs in a given month across the 14 years of the simulation for which we have observational data for comparison (1994-2007). For clarity, Fig. 6 shows this fit for a single month only, January 2006, for observations and modelled CTL cases. We take this approach in order to compare the observations to both the CCAM and ACCESS simulations. At the time of this work, ACCESS meteorology was forced only with sea surface temperatures and ran on a 360-day calendar, as described in Sect. 3. This
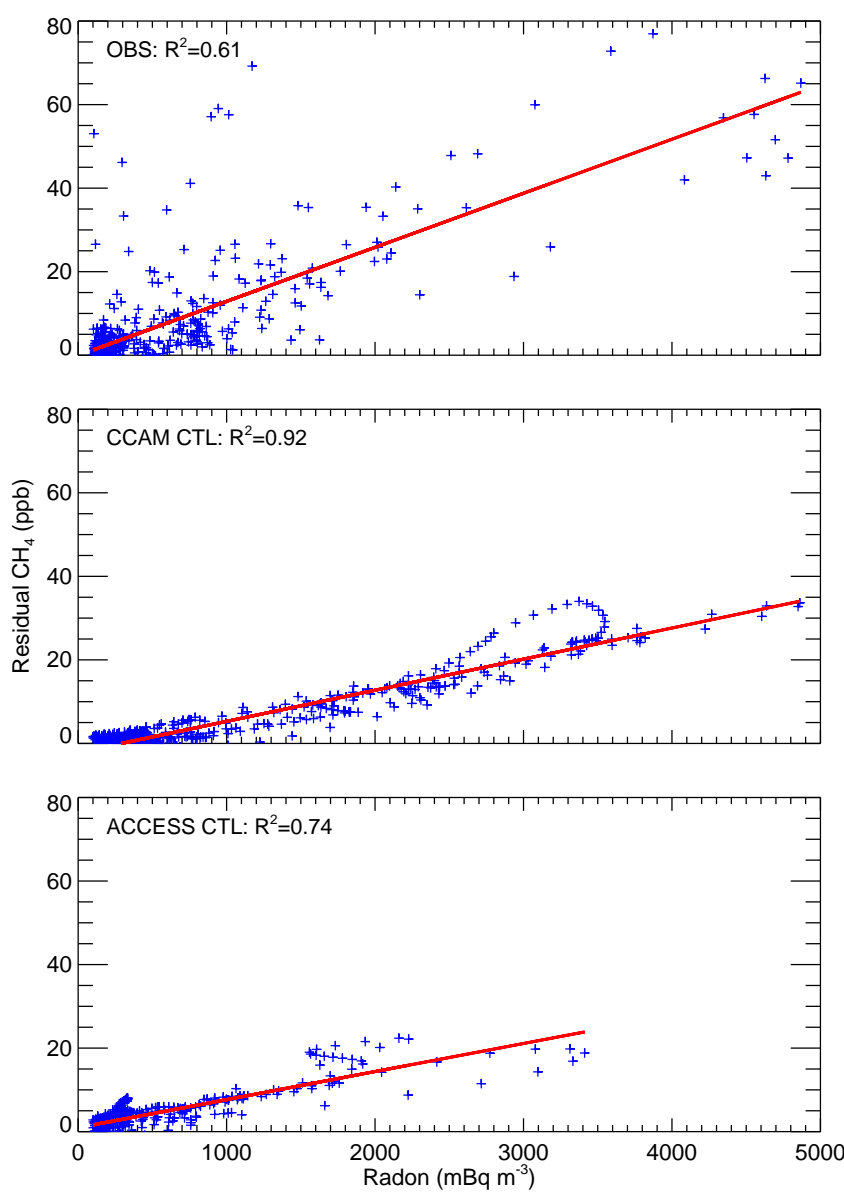

Figure 6. Scatter plots of methane to radon, with linear fits for January 2006. The upper panel shows the observational data, the middle panel the CCAM data and the lower panel the ACCESS data.

means that we do not expect the timing of individual "events" (non-baseline periods) in ACCESS to match the observations well enough for a direct comparison. We do however expect that the seasonal-scale meteorology will be realistic enough to provide seasonal fetch changes that are comparable to the real meteorology and fetch patterns at Cape Grim. Averaging results up to a seasonal timescale allows direct comparison of all three data sets (the observations and both models). The observations show more scatter than the model output, and this is reflected in lower $R^{2}$ values, in this case 0.61 for the observations and 0.92 and 0.74 for CCAM and ACCESS respectively. The slope of the line gives the methane residual to radon ratio. We determine the ratio this way to preserve the temporal pairing of the methane and radon concentrations. We also calculate linear fits for each individual month as per Fig. 6, and use the standard deviation of the slopes for each of the 14 months as a measure of the uncertainty on the methane-radon ratios.

Figure 7 shows the mean seasonal cycle of the methane residual to radon ratio for each methane scenario, compared to observed ratios. The observed ratios are smallest in win- 

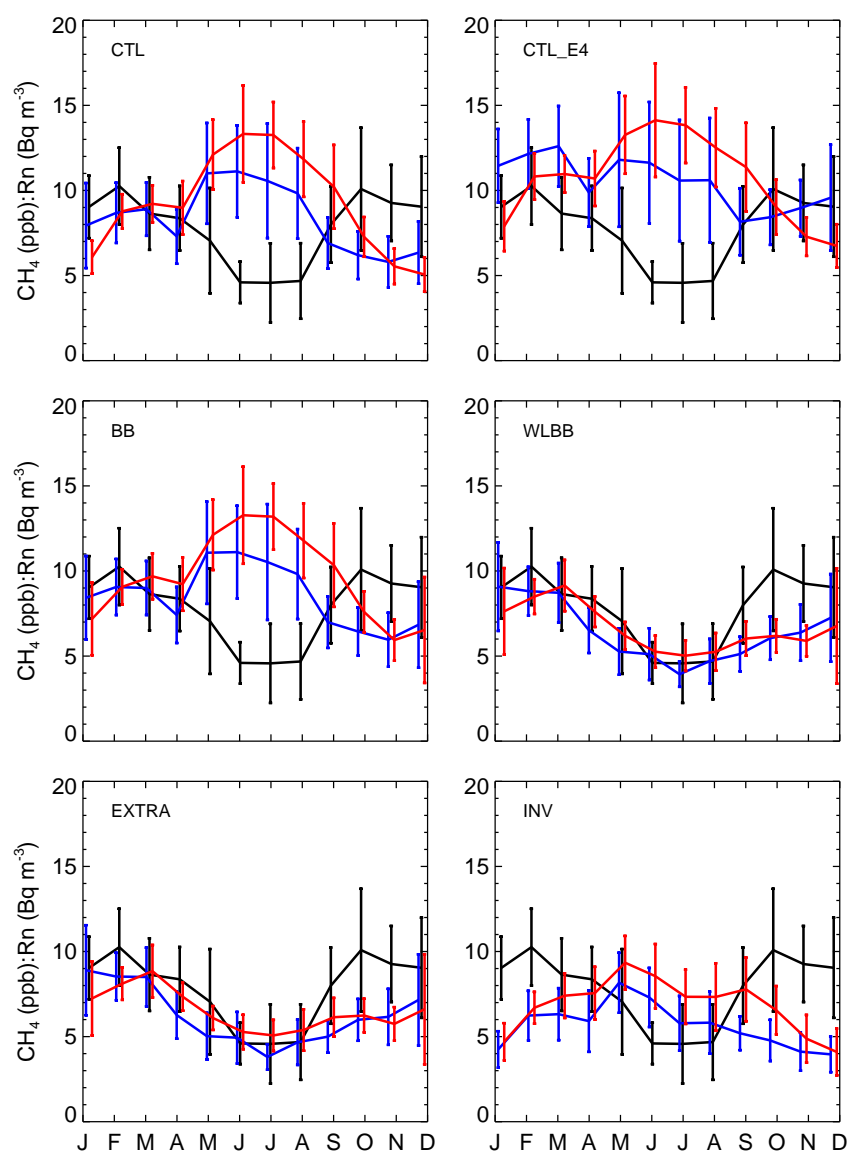

Figure 7. Mean seasonal cycle of residual methane to radon ratios for each of the six methane emission scenarios. Observations are shown in black, ACCESS results in blue and CCAM results in red.

ter (June to August) and are largest in spring and summer (October to February). The modelled ratios show three patterns depending on the methane scenario. The CTL, CTL_E4 and $\mathrm{BB}$ scenarios show maximum ratios in winter, while the WLBB and EXTRA scenarios show minimum ratios in winter, which is more consistent with the observations. The INV scenario is intermediate between the other cases, also showing somewhat elevated winter ratios. For any given scenario, the ratios for the two different models compare well, much better than if either of the individual trace gases (methane or radon) are directly compared, as was the case in Fig. 4 where the monthly mean methane is shown for both models. This illustrates the benefit of using the radon simulation to account for some of the transport differences between the models.

Overall the WLBB and EXTRA scenarios give ratios that are a better fit to those observed. For the southeastern Australian region, the major difference from the group of CTLbased cases is in the representation of wetlands. These results suggest that the large winter wetland fluxes in the CTLbased scenarios taken from Matthews and Fung (1987) and Fung et al. (1991) are not realistic and that annual mean fluxes should be close to the anthropogenic-only inventory

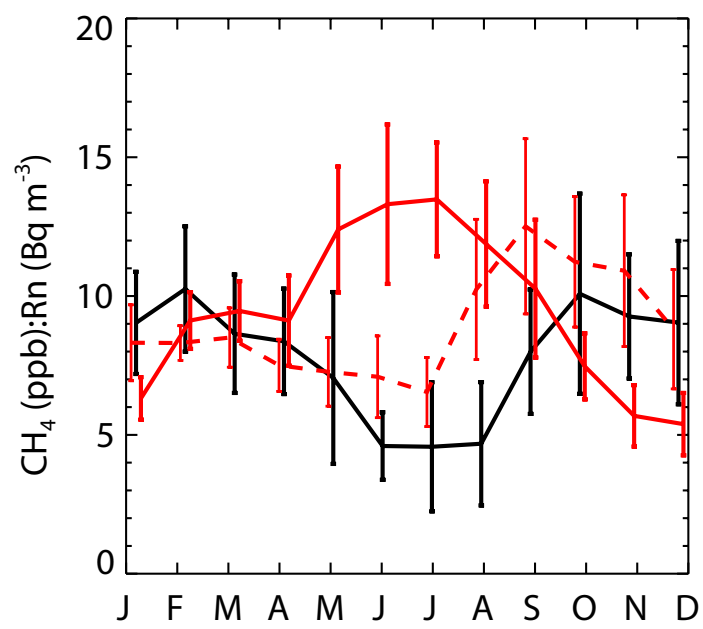

Figure 8. Mean seasonal cycle of residual methane to radon ratios for the CTL methane scenario (red, solid) and the CTL methane fluxes shifted forward in time by three months (red, dashed) compared to the observations (black). Both simulations used the CCAM model.

estimates noted in Sect. 3.1. For all scenarios (except perhaps CTL_E4) there is a discrepancy between the observed and modelled ratios in the austral spring (September to November) with the observed ratios being larger than the modelled ones. This suggests that the methane flux scenarios tested here underestimate methane fluxes in spring. We will discuss this further in Sect. 5.

While the ratios from the CTL_E4 scenario agree reasonably with those observed in September-October, this occurs mainly because the CTL_E4 scenario gives generally higher ratios all year round compared to the CTL case. This is expected since the CTL_E4 fluxes for southeastern Australia gradually increase in time relative to the CTL fluxes (Fig. 3b). There is weak evidence of an increase in ratio over time for CTL_E4 compared to CTL but the large seasonal and interannual variability means that we can have little confidence in the calculated trends and which might compare better to the observations. The seasonality of ratios is similar between CTL and CTL_E4 (and a poor fit to observed seasonality) although the difference between summer and winter ratios is smaller in CTL_E4 especially in the ACCESS case. This may be due to changes in the spatial distribution of fluxes between CTL and CTL_E4. Overall CTL_E4 does not agree well with the observations.

\section{Discussion and concluding remarks}

Forward modelling of a range of methane flux scenarios gives us the opportunity to compare those results with the measurement record at Cape Grim for the same period, offering insights into which of the flux scenarios appear to be most representative of southeastern Australian methane 
fluxes. The WLBB and EXTRA flux scenarios appear to be the best fit to the observed data. Like Fraser et al. (2011), we find that anthropogenic methane emissions taken from inventories for southeastern Australia look quite reasonable in magnitude at around $2.5 \mathrm{Tg} \mathrm{y}^{-1}$. However, there remain questions about the scale and timing of a wetland component to $\mathrm{CH}_{4}$ emissions.

Our analysis reveals that mismatches in the CTL, CTL_E4 and $\mathrm{BB}$ scenarios were due to high wetland emissions during the winter, suggesting that the wintertime wetland flux is overestimated in these scenarios. The Cape Grim observations point to somewhat larger springtime fluxes than are represented in the WLBB or EXTRA emission scenarios (or indeed any of the other tracers). Although the wintertime maxima of the CTL-style emission scenarios (driven by a wetland emission component) is clearly not warranted by the observational data, a shift in the wetland emissions from austral winter to spring might result in a better fit to the observations.

To test this we have run CCAM from December 1, 1993 to December 31, 2007 for radon and two methane scenarios, the standard CTL case and with the same CTL fluxes shifted forward in time by 3 months (across the whole globe). For southeastern Australia, this means that methane fluxes are elevated between August and January instead of between May and October. The output from the simulation has been processed similarly to the previous cases and Fig. 8 shows the seasonal cycle of methane-to-radon ratio. The case with temporally shifted fluxes clearly fits the observations better than the original CTL fluxes, although a 4-month shift in the fluxes might improve the comparison with observations further. The shifted fluxes case does not simulate a low enough methane minimum in winter. This may be a consequence of shifting the CTL fluxes across the whole globe rather than just for southeastern Australia. For example a large flux just to the north of the region we define occurs in February in the CTL fluxes and consequently gets shifted to May in the sensitivity test performed here. Nevertheless, this simulation supports the need for a shift in wetland emissions from austral winter to spring and summer.

A shift of this nature is plausible given that wetland methane emissions have both a soil moisture and soil temperature dependence, making it possible that southeastern Australian methane emissions from wetlands are highest in springtime when there is available moisture and warmer temperatures. Indeed, Bloom et al. (2012) use satellite column observations of $\mathrm{CH}_{4}$ from the SCanning Imaging Absorption spectroMeter for Atmospheric CHartographY (SCIAMACHY) coupled with a measure of equivalent water height from the Gravity Recovery and Climate Experiment (GRACE) to model seasonal variability in wetland methane emissions. For our region of interest across the years 20032008, they find the minimum in methane emissions from southeastern Australian wetlands occurs in late autumn and winter with a rapid rise through spring giving a maximum in October and November (A. Fraser, personal communication, 2012) in accordance with the Cape Grim observations. However, the magnitude they predict for this wetland flux is around $2.5 \mathrm{Tgy}^{-1}$. This seems larger than indicated by the Cape Grim data; of the six emission scenarios considered in this work, annual means for total $\mathrm{CH}_{4}$ flux (including all anthropogenic emissions) in our defined region range between 2.4 (WLBB) and 4 (CTL) $\mathrm{Tg}^{-1}$ (Fig. 3b). Moreover, the additional $1.6 \mathrm{Tg} \mathrm{y}^{-1}$ in the CTL emission scenario comes from a wintertime wetland flux that we find no evidence for in the observations. It should be noted however that in Fraser et al. (2011) the GRACE data used were scaled to match a prior emissions estimate. We therefore find that the GRACE data have plausible seasonality for southeastern Australia but that the magnitude is too large to offer a realistic assessment of the scale of southeastern Australian wetland emissions given the Cape Grim observations. Nevertheless, we believe the seasonality of the GRACE data lends credibility to the idea that a springtime wetland emission of around the magnitude represented in the CTL-style emissions scenarios for winter may be responsible for the discrepancy between our modelled WLBB/EXTRA results and the observations.

Although our hypothesis that the timing of wetland methane emissions in the inventories may be off by 3-4 months is plausible and supported by other data, we cannot entirely rule out another source for the additional austral spring methane emissions. For instance, ruminant emissions from cattle are the single biggest contributor to Australia's anthropogenic methane emissions. Seasonality in ruminant emissions that is not captured by the inventories, due to changes in feed or cattle number, might also be responsible for the austral springtime maximum observed. This explanation is offered in Wang and Bentley (2002) to account for a springtime spike in their estimated emissions from a region roughly equivalent to Victoria and New South Wales (their region D) when fitting the Cape $\mathrm{Grim}_{\mathrm{CH}}$ data. While this would concur with our results, overall Wang and Bentley (2002) find a significant reduction (around $40 \%$ ) in the inversion-estimated $\mathrm{CH}_{4}$ fluxes for southeastern Australia compared to the 1997 inventory (Table 3). This does not agree with this work or with Fraser et al. (2011), which both suggest that the total methane emissions in the inventories for southeastern Australia are consistent with the Cape Grim data. The methodology in Wang and Bentley (2002) is to invert a series of 22 individual non-baseline "events" each lasting between 2 and 11 days. The inversion results for each event show considerable variability giving fluxes ranging from $0-7 \mathrm{Tgy}^{-1}$ for region D. Such high variability would appear to be unrealistic and may be caused by errors in the modelling of $\mathrm{CH}_{4}$ concentration at Cape Grim for a given Australian flux. Thus the inversion estimated fluxes are unlikely to be representative of the true flux.

This study used 14 years of observational data, and output from two models (CCAM and ACCESS) to investigate methane emissions data for southeastern Australia. Inclusion 
of biomass burning emissions produces unrealistically high $\mathrm{CH}_{4}$ concentrations at Cape Grim, but this is most likely due to the coarse spatio-temporal resolution of the models and the unrealistic injection of these emissions into the lowest model level. In future, continuous $\mathrm{CH}_{4}$ measurements made from unmanned aerial vehicles (UAVs) around large fire plumes may be a better way to verify the scale of emissions from large biomass burning events. By comparing a range of methane emission scenarios run in the models, we find that the large wintertime wetland flux in the CTL-style scenarios is unrealistic, but also that there is a deficit in spring in all six emission scenarios. This deficit is present in even the WLBB and EXTRA scenarios which otherwise provide a good fit to the observational data. It is notable that these two emission scenarios have a very small wetland emission component compared to the CTL-style scenarios. We suggest then, that it may be a springtime wetland emission that is missing from these scenarios. Finally, we note that given the size and uncertainty associated with the biogenic $\mathrm{CH}_{4}$ fluxes, it is difficult to make assessments about changes in anthropogenic $\mathrm{CH}_{4}$ emissions in southeastern Australia from the Cape Grim data set alone using this approach. Additional in situ instrumented sites for the continuous measurement of methane on the Australian mainland would help to answer questions about the scale and timing of wetland emissions as well as providing more stringent constraints on changes to the anthropogenic flux from southeastern Australia.

Acknowledgements. We thank AGAGE and Cape Grim staff, along with all the TransCom- $\mathrm{CH}_{4}$ participants, but in particular Prabir Patra for his efforts in setting up the experiment. This work has been undertaken as part of the Australian Climate Change Science Programme, funded jointly by the Department of the Environment, the Bureau of Meteorology and CSIRO. Model simulations were undertaken on the NCI National Facility in Canberra, Australia, which is supported by the Australian Commonwealth Government. We thank the reviewers for their helpful comments.

Edited by: P. Monks

\section{References}

Aoki, S., Nakazawa, T., Murayama, S., and Kawaguchi, S.: Measurements of atmospheric methane at the Japanese Antarctic station, Syowa, Tellus B, 44, 273-281, 1992.

Biraud, S., Ciais, P., Ramonet, M., Simmonds, P., Kazan, V., Monfray, P., O'Doherty, S., Spain, T. G., and Jennings, S. G.: European greenhouse gas emissions estimated from continuous atmospheric measurements and radon 222 at Mace Head, Ireland, J. Geophys. Res., 105, 1351-1366, 2000.

Bloom, A. A., Palmer, P. I., Fraser, A., and Reay, D. S.: Seasonal variability of tropical wetland $\mathrm{CH}_{4}$ emissions: the role of the methanogen-available carbon pool, Biogeosciences, 9, 28212830, doi:10.5194/bg-9-2821-2012, 2012.
Bousquet, P., Ciais, P., Miller, J. B., Dlugokencky, E. J., Hauglustaine, D. A., Prigent, C., Van der Werf, G. R., Peylin, P., Brunke, E. G., Carouge, C., Langenfelds, R. L., Lathière, J., Papa, F., Ramonet, M., Schmidt, M., Steele, L. P., Tyler, S. C., and White, J.: Contribution of anthropogenic and natural sources to atmospheric methane variability, Nature, 443, 439-443, doi:10.1038/nature05132, 2006.

Bousquet, P., Ringeval, B., Pison, I., Dlugokencky, E. J., Brunke, E.G., Carouge, C., Chevallier, F., Fortems-Cheiney, A., Frankenberg, C., Hauglustaine, D. A., Krummel, P. B., Langenfelds, R. L., Ramonet, M., Schmidt, M., Steele, L. P., Szopa, S., Yver, C., Viovy, N., and Ciais, P.: Source attribution of the changes in atmospheric methane for 2006-2008, Atmos. Chem. Phys., 11, 3689-3700, doi:10.5194/acp-11-3689-2011, 2011.

Chambers, S., Williams, A. G., Zahorowski, W., Griffiths, A., and Crawford, J.: Separating remote fetch and local mixing influences on vertical radon measurements in the lower atmosphere, Tellus B, 63, 843-859, doi:10.1111/j.1600-0889.2011.00565.x, 2011.

Collier, M. A.: The CSIRO NCEP/NCAR/DOE $R-1 / R-2$ archive, CSIRO Atmospheric Research technical paper 68, Aspendale, Victoria, Australia, available at: http://www.cmar.csiro.au/ e-print/open/collier_2004a.pdf, 2004.

Corbin, K. D. and Law, R. M.: Extending atmospheric $\mathrm{CO}_{2}$ and tracer capabilities in ACCESS, CAWCR Technical Report 035, Aspendale, Victoria, Australia, available at: http://www.cawcr. gov.au/publications/technicalreports/CTR_035.pdf, 2011.

Cunnold, D., Steele, L., Fraser, P., Simmonds, P., Prinn, R., Weiss, R., Porter, L., O’Doherty, S., Langenfelds, R., Krummel, P., Wang, H., Emmons, L., Tie, X., and Dlugokencky, E.: In situ measurements of atmospheric methane at GAGE/AGAGE sites during 1985-2000 and resulting source inferences, J. Geophys. Res.-Atmos., 107, 4225, doi:10.1029/2001JD001226, 2002.

Dlugokencky, E. J., Bruhwiler, L., White, J. W. C., Emmons, L. K., Novelli, P. C., Montzka, S. A., Masarie, K. A., Lang, P. M., Crotwell, A. M., Miller, J. B., and Gatti, L. V.: Observational constraints on recent increases in the atmospheric $\mathrm{CH}_{4}$ burden, Geophys. Res. Lett., 36, L18803, doi:10.1029/2009GL039780, 2009.

Fraser, A., Chan Miller, C., Palmer, P. I., Deutscher, N. M., Jones, N. B., and Griffith, D. W. T.: The Australian methane budget: interpreting surface and train-borne measurements using a chemistry transport model, J. Geophys. Res., 116, D20306, doi:10.1029/2011JD015964, 2011.

Fung, I., John, J., Lerner, J., Matthews, E., Prather, M., Steele, L. P., and Fraser, P. J.: Three-dimensional model synthesis of the global methane cycle, J. Geophys. Res., 96, 13033-13065, 1991.

Griffiths, A. D., Zahorowski, W., Element, A., and Werczynski, S.: A map of radon flux at the Australian land surface, Atmos. Chem. Phys., 10, 8969-8982, doi:10.5194/acp-10-8969-2010, 2010.

Houweling, S., Kaminski, T., Dentener, F., Lelieveld, J., and Heimann, M.: Inverse modeling of methane sources and sinks using the adjoint of a global transport model, J. Geophys. Res., 104, 26137-26160, 1999.

Ito, A. and Inatomi, M.: Use of a process-based model for assessing the methane budgets of global terrestrial ecosystems and evaluation of uncertainty, Biogeosciences, 9, 759-773, doi:10.5194/bg9-759-2012, 2012. 
Kalnay, E., Kanamitsu, M., Kistler, R., Collins, W., Deaven, D., Gandin, L., Iredell, M., Saha, S., White, G., Woollen, J., Zhu, Y., Chelliah, M., Ebisuzaki, W., Higgins, W., Janowiak, J., Mo, K., Ropelewski, C., Wang, J., Leetmaa, A., Reynolds, R., Jenne, R., and Jospher, D.: The NCEP/NCAR 40-year reanalysis project, B. Am. Meteorol. Soc., 77, 437-471, 1996.

Kirschke, S., Bousquet, P., Ciais, P., Saunois, M., Canadell, J. G., Dlugokencky, E. J., Bergamaschi, P., Bergmann, D., Blake, D. R., Bruhwiler, L., Cameron-Smith, P., Castaldi, S., Chevallier, F., Feng, L., Fraser, A., Heimann, M., Hodson, E. L., Houweling, S., Josse, B., Fraser, P. J., Krummel, P. B., Lamarque, J.-F., Langenfelds, R. L., Le Quéré, C., Naik, V., O’Doherty, S., Palmer, P. I., Pison, I., Plummer, D., Poulter, B., Prinn, R. G., Rigby, M., Ringeval, B., Santini, M., Schmidt, M., Shindell, D. T., Simpson, I. J., Spahni, R., Steele, L. P., Strode, S. A., Sudo, K., Szopa, S., van der Werf, G. R., Voulgarakis, A., van Weele, M., Weiss, R. F., Williams, J. E., and Zeng, G.: Three decades of global methane sources and sinks, Nat. Geosci., 6, 813-823, doi:10.1038/NGEO1955, 2013.

Krummel, P., Fraser, P., Steele, L., Derek, N., Rickard, C., Ward, J., Somerville, N. T., Cleland, S. J., Dunse, B., Langenfelds, R., Baly, S. B., and Leist, M.: The AGAGE in situ program for non- $\mathrm{CO}_{2}$ greenhouse gases at Cape Grim, 2009-2010, in: Baseline Atmospheric Program (Australia), 2009-2010, edited by: Derek, N., Krummel, P. B., and Cleland, S. J., Australian Bureau of Meteorology and CSIRO Marine and Atmospheric Research, Aspendale, Victoria, Australia, 56-70, 2014.

Langenfelds, R., Steele, L., Gregory, R. L., Krummel, P., Spencer, D., and Howden, R.: Atmospheric methane, carbon dioxide, hydrogen, carbon monoxide and nitrous oxide from Cape Grim flask air samples analysed by gas chromatography, in: Baseline Atmospheric Program (Australia), 2009-2010, edited by: Derek, N., Krummel, P. B., and Cleland, S. J., Australian Bureau of Meteorology and CSIRO Marine and Atmospheric Research, Aspendale, Victoria, Australia, 45-49, 2014.

MacFarling Meure, C., Etheridge, D., Trudinger, C., Steele, P., Langenfelds, R., van Ommen, T., Smith, A., and Elkins, J.: Law dome $\mathrm{CO}_{2}, \mathrm{CH}_{4}$ and $\mathrm{N}_{2} \mathrm{O}$ ice core records extended to 2000 years BP, Geophys. Res. Lett., 33, L14810, doi:10.1029/2006GL026152, 2006.

Matthews, E. and Fung, I.: Methane emission from natural wetlands: global distribution, area, and environmental characteristics of sources, Global Biogeochem. Cy., 1, 61-86, doi:10.1029/GB001i001p00061, 1987.

McGregor, J. L.: C-CAM: Geometric aspects and dynamical formulation, CSIRO Atmospheric Research Technical Paper 70, Aspendale, Victoria, Australia, available at: http://www.cmar.csiro. au/e-print/open/mcgregor_2005a.pdf, 2005.

McGregor, J. L. and Dix, M. R.: An updated description of the Conformal Cubic Atmospheric Model, in: High Resolution Numerical Modelling of the Atmosphere and Ocean, edited by: Hamilton, K. and Ohfuchi, W., Springer, Berlin, 51-76, 2008.

Miller, S. M., Wofsy, S. C., Michalak, A. M., Kort, E. A., Andrews, A. E., Biraud, S. C., Dlugokencky, E. J., Eluszkiewicz, J., Fischer, M. L., Janssens-Maenhout, G., Miller, B. R., Miller, J. B., Montzka, S. A., Nehrkorn, T., and Sweeney, C.: Anthropogenic emissions of methane in the United States, P. Natl. Acad. Sci. USA, 110, 20018-20022, doi:10.1073/pnas.1314392110, 2013.
Olivier, J. G. J. and Berdowski, J. J. M.: Global emissions sources and sinks, in: The Climate System, edited by: Berdowski, J. J. M., Guicherit, R., and Heij, B. J., A. A. Balkema Publishers/Swets \& Zeitlinger Publishers, Lisse, The Netherlands, 33-78, 2001.

Olivier, J. G. J., van Aardenne, J. A., Dentener, F., Ganzeveld, L., and Peters, J. A. H. W.: Recent trends in global greenhouse gas emissions: regional trends and spatial distribution of key sources, in: Non- $\mathrm{CO}_{2}$ Greenhouse Gases (NCGG-4), edited by: van Amstel, A., Millpress, Rotterdam, 325-330, 2005.

Patra, P. K., Houweling, S., Krol, M., Bousquet, P., Bruhwiler, L., and Jacob, D.: Protocol for TransCom $\mathrm{CH}_{4}$ intercomparison, Version 7, available at: http://transcom.project.asu.edu/ pdf/transcom/T4.methane.protocol_v7.pdf (last access: August 2014), 2010.

Patra, P. K., Houweling, S., Krol, M., Bousquet, P., Belikov, D., Bergmann, D., Bian, H., Cameron-Smith, P., Chipperfield, M. P., Corbin, K., Fortems-Cheiney, A., Fraser, A., Gloor, E., Hess, P., Ito, A., Kawa, S. R., Law, R. M., Loh, Z., Maksyutov, S., Meng, L., Palmer, P. I., Prinn, R. G., Rigby, M., Saito, R., and Wilson, C.: TransCom model simulations of $\mathrm{CH}_{4}$ and related species: linking transport, surface flux and chemical loss with $\mathrm{CH}_{4}$ variability in the troposphere and lower stratosphere, Atmos. Chem. Phys., 11, 12813-12837, doi:10.5194/acp-1112813-2011, 2011.

Prinn, R., Weiss, R., Fraser, P., Simmonds, P., Cunnold, D., Alyea, F., O’Doherty, S., Salameh, P., Miller, B., Huang, J., Wang, R., Hartley, D., Harth, C., Steele, L., Sturrock, G., Midgley, P., and McCulloch, A.: A history of chemically and radiatively important gases in air deduced from ALE/GAGE/AGAGE, J. Geophys. Res.-Atmos., 105, 1775117792, doi:10.1029/2000JD900141, 2000.

Rigby, M., Prinn, R. G., Fraser, P. J., Simmonds, P. G., Langenfelds, R. L., Huang, J., Cunnold, D. M., Steele, L. P., Krummel, P. B., Weiss, R. F., O’Doherty, S., Salameh, P. K., Wang, H. J., Harth, C. M., Muehle, J., and Porter, L. W.: Renewed growth of atmospheric methane, Geophys. Res. Lett., 35, L22805, doi:10.1029/2008GL036037, 2008.

Ringeval, B., de Noblet-Ducoudré, N., Ciais, P., Bousquet, P., Prigent, C., Papa, F., and Rossow, W. B.: An attempt to quantify the impact of changes in wetland extent on methane emissions on the seasonal and interannual time scales, Global Biogeochem. Cy., 24, GB2003, doi:10.1029/2008GB003354, 2010.

Schmidt, M., Graul, R., Sartorius, H., and Levin, I.: Carbon dioxide and methane in continental Europe: a climatology, and ${ }^{222}$ Radon-based emission estimates, Tellus B, 48, 457-473, 1996.

Sofiev, M., Vankevich, R., Ermakova, T., and Hakkarainen, J.: Global mapping of maximum emission heights and resulting vertical profiles of wildfire emissions, Atmos. Chem. Phys., 13, 7039-7052, doi:10.5194/acp-13-7039-2013, 2013.

Sussmann, R., Forster, F., Rettinger, M., and Bousquet, P.: Renewed methane increase for five years (2007-2011) observed by solar FTIR spectrometry, Atmos. Chem. Phys., 12, 4885-4891, doi:10.5194/acp-12-4885-2012, 2012.

Thatcher, M. J. and McGregor, J. L.: Using a scale-selective filter for dynamical downscaling with the Conformal Cubic Atmospheric Model, Mon. Weather Rev., 137, 1742-1752, 2009.

Thoning, K. W., Tans, P. P., and Komhyr, W. D.: Atmospheric carbon dioxide at Mauna Loa Observatory, 2, Analysis of the 
NOAA/GMCC data, 1974-1985, J. Geophys. Res., 94, 8549$8565,1989$.

van Aardenne, J. A., Dentener, F. J., Olivier, J. G. J., Klein Goldewijk, C. G. M., and Lelieveld, J.: A $1^{\circ} \times 1^{\circ}$ resolution data set of historical anthropogenic trace gas emissions for the period 1890 1990, J. Geophys. Res., 15, 909-928, 2001.

van der Werf, G. R., Randerson, J. T., Giglio, L., Collatz, G. J., Kasibhatla, P. S., and Arellano Jr., A. F.: Interannual variability in global biomass burning emissions from 1997 to 2004, Atmos. Chem. Phys., 6, 3423-3441, doi:10.5194/acp-6-3423-2006, 2006.

Wada, A., Matsueda, H., Murayama, S., Taguchi, S., Hirao, S., Yamazawa, H., Moriizumi, J., Tsuboi, K., Niwa, Y., and Sawa, Y.: Quantification of emission estimates of $\mathrm{CO}_{2}, \mathrm{CH}_{4}$ and $\mathrm{CO}$ for East Asia derived from atmospheric radon-222 measurements over the western North Pacific, Tellus B, 65, 18037, doi:10.3402/tellusb.v65i0.18037, 2013.

Wang, Y. P. and Bentley, S. T.: Development of a spatially explicit inventory of methane emissions from Australia and its verification using atmospheric concentration data, Atmos. Environ., 36, 4965-4975, 2002.

Whittlestone, S. and Zahorowski, W.: The Cape Grim Huge Radon detector, in: Baseline Atmospheric Program (Australia) 92, edited by: Dick, A. L. and Fraser, P. J., Australian Bureau of Meteorology and CSIRO Marine and Atmospheric Research, Aspendale, Victoria, Australia, 26-30, 1995.
Whittlestone, S. and Zahorowski, W.: Baseline radon detectors for shipboard use: development and deployment in the First Aerosol Characterisation experiment (ACE 1), J. Geophys. Res., 103, 16743-16751, 1998.

Williams, A. G., Zahorowski, W., Chambers, S., Griffiths, A. Hacker, J. M., Element, A., and Werczynski, S.: The vertical distribution of radon in clear and cloudy daytime terrestrial boundary layers, J. Atmos. Sci., 68, 155-174, doi:10.1175/2010JAS3576.1, 2011.

Williams, A. G., Chambers, S., and Griffiths, A.: Bulk mixing and decoupling of the nocturnal stable boundary layer characterized using a ubiquitous natural tracer, Bound.-Lay. Meteorol., 149, 381-402, doi:10.1007/s10546-013-9849-3, 2013.

Wilson, S., Dick, A., Fraser, P., and Whittlestone, S.: Nitrous oxide flux estimates for South-Eastern Australia, J. Atmos. Chem., 26, 169-188, 1997.

Yan, X., Akiyama, H., Yagi, K., and Akimoto, H.: Global estimations of the inventory and mitigation potential of methane emissions from rice cultivation conducted using the 2006 Intergovernmental Panel on Climate Change Guidelines, Global Biogeochem. Cy., 23, GB2002, doi:10.1029/2008GB003299, 2009.

Zahorowski, W., Chambers, S. D., and Henderson-Sellers, A.: Ground based radon-222 observations and their application to atmospheric studies, J. Environ. Radioact., 76, 3-33, 2004.

Zahorowski, W., Williams, A. G., Chambers, S. D., Crawford, J., and Griffiths, A.: Radon and radon daughters, in: Baseline Atmospheric Program (Australia), 2009-2010, edited by: Derek, N. and Krummel, P. B. and Cleland, S. J., Australian Bureau of Meteorology and CSIRO Marine and Atmospheric Research, Aspendale, Victoria, Australia, 33-38, 2014. 